\title{
将来の原子力発電
}

\section{Future Nuclear Power Plant}

\section{田中 知*}

Satoru TANAKA

Key Words: Generation III + Reactor, Generation IV Reactor, GIF, Small Modular Reactor, High-temperature Gas-cooled Reactor

\section{1.はじめに}

東京電力福島第一原子力発電所事故後、我が国の原子力 発電所における安全審査基準が改訂された。あらかじめ想 定していた「設計基準事象」を大きく超える事象に対して、 原子炉内の核燃料冷却や制御が不可能となり炉心が重大な 損傷を受ける事象をシビアアクシデントとよぶ。今回の 事故を受けて、新安全基準では、耐震・津波性能や電源な どの信頼性対策が強化されるとともに、放射性物質の拡散 抑制などのシビアアクシデント対策を強化するための対策 も併せて新設された。現在、新安全基準による再稼働に向 けての安全審査が行われている。一方、国外の原子力発電 所は、福島第一事故後シビアアクシデントを想定したコン ピュータシミュレーションによる評価であるストレステス 卜などの安全確認を経て運転が継続されているし、アジア を中心とした原子力発電所の建設もしくは建設計画は依然 として一定の規模を保っている。今後の原子力発電所はよ
り安全性を向上させたものでなければならないことは論を 待たないが、従来型炉に加えて、中・小型炉や、小型モジュー ル炬、高温ガス炉なども注目されている。本稿では、発電 用原子炉開発の進展について概観し、我が国において開発 を進めてきた次世代軽水炉、及び第 4 世代原子力システム 国際フォーラム (GIF: Generation IV International Forum)、将 来注目されている小型モジュール炉、高温ガス炉について 解説する。

\section{2. 発電用原子炉開発の進展 ${ }^{1)}$}

Fig.1 は、発電用原子炉開発のこれまでの経緯と、今後 の展望を示したものである。1950 年代に商業用原子炉（第 1 世代）が運転開始されてから、安全性の向上等を目的と して原子炬の開発は継続的に行われきた。初期の我が国の 原子力発電所は第 2 世代炉であったが、その後第 3 世代炉 の原子力発電所が建設され、現在の最新型原子炉は第 $3+$ 世代炉であり、ABWR, APWR 等がある。さらに、2030 年

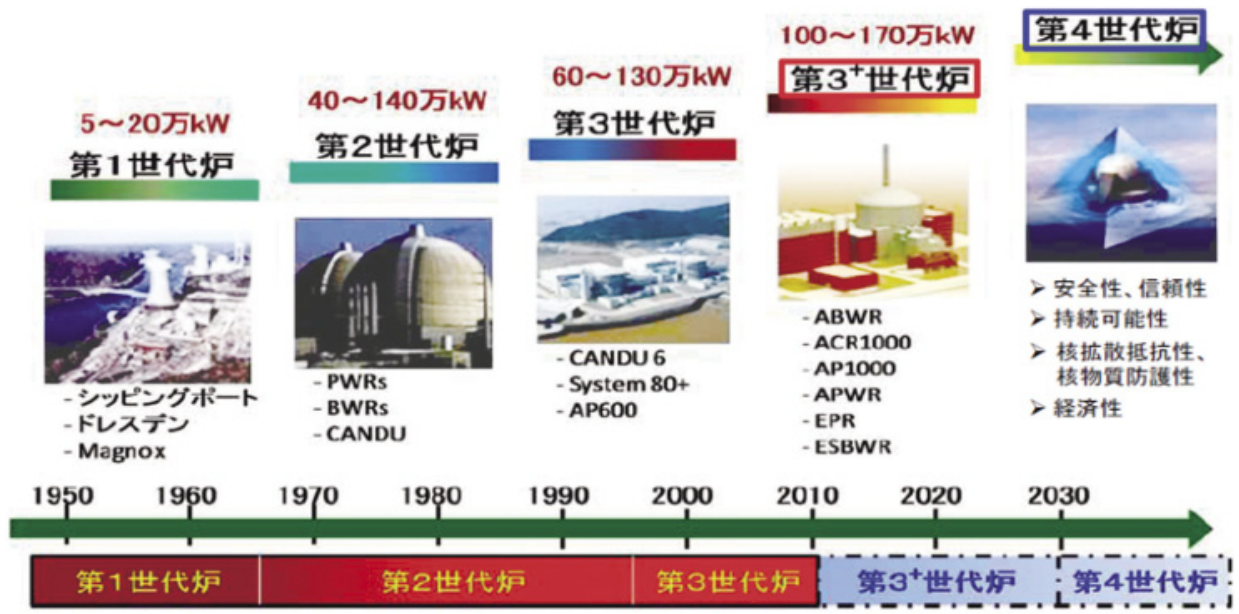

Fig.1 Generations of Nuclear Power Plant ${ }^{1)}$

* 東京大学大学院工学系研究科 原子力国際専攻（ $\bar{\top} 113-8656$ 東京都文京区本郷 7-3-1）

Department of Nuclear Engineering and Management, School of Engineering, The University of Tokyo (7-3-1 Hongo, Bunkyo-ku, Tokyo, 113-8656 Japan) 


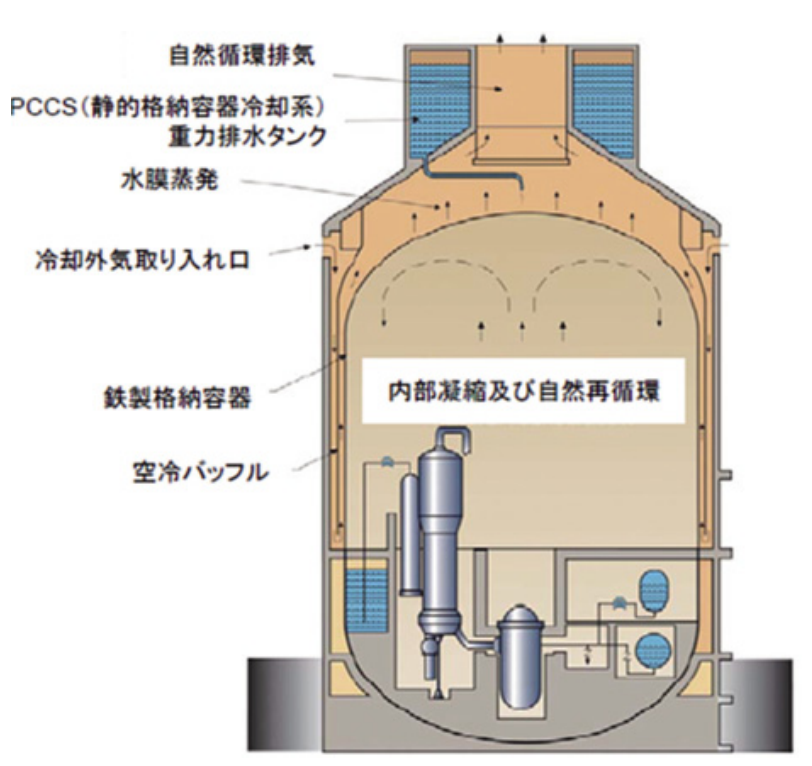

Fig.2 AP1000 Passive Containment Cooling System ${ }^{1)}$

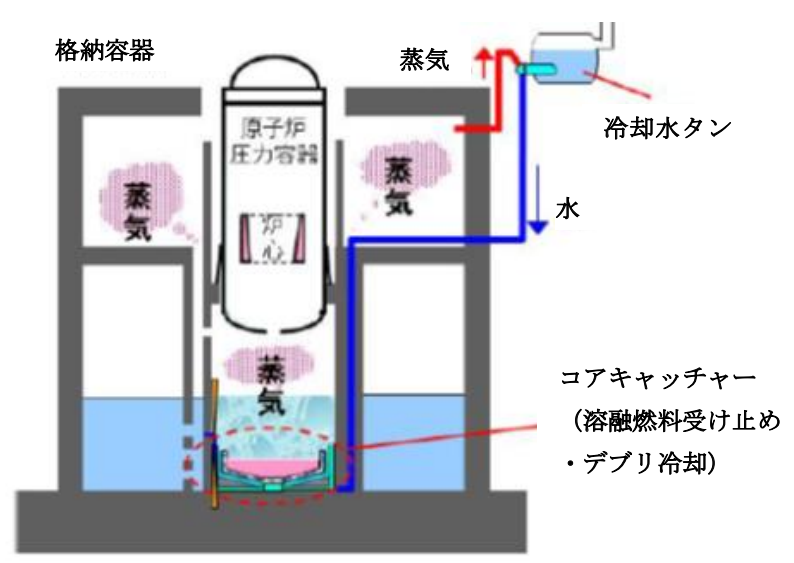

Fig.3 Concept of core catcher ${ }^{1)}$

以降の炉概念として、安全性、信頼性や核拡散抵抗性が高 い第 4 世代炉の開発が進んでいる。ここで、核拡散抵抗性 とは、核物質の軍事転用や核技術の不正使用のやりにくさ の程度を示す指標であり、核拡散抵抗性が高いとは、その ような不正などを行いにくいということを意味している。

現在の最新型炉である第 $3+$ 世代炉は、機器の信頼性や 耐震性の向上、シビアアクシデント対策の導入など、既存 の沸騰水型軽水炉 (BWR)、加圧水型軽水炉 (PWR) の大部 分である第 2 世代炉と比較して安全性が向上している。例 えば、次のような特徴がある。

1) 耐震性の向上: 主要配管の短縮化、機器の耐震性の向上。

2) 信頼性の向上 : 冷却系統の多重化·系統分離、制御棒の 多様化（電動、水圧方式）、耐腐食性の向上等。
3) 受動的安全設備の導入：重力落下式の注水冷却、自然循 環による炉冷却等。

4) シビアアクシデント対策：コアキャッチャー等。

受動的安全設備とは、重力や圧力差を利用した注水や自 然循環冷却等、自然の力を積極的に利用した受動的（静的） 安全設備を非常用炉心冷却系 (ECCS) に採用し安全性の向 上を図ったものである。例として、静的格納容器冷却系、 自然再循環を備えた AP1000を Fig.2に示す。シビアアクシ デント対策としてのコアキャッチャーは、原子炉内の核燃 料が溶融し、圧力容器が破損するに至った場合にも溶融し た燃料を受け止め、冷却水等により冷却することで格納容 器の破損を回避するものであり、BWR での概念図を Fig.3 に示す。

\section{3. 次世代軽水炉開発 ${ }^{11}$}

我が国では 1975 年頃から軽水炉改良標準化計画が始ま り、第一次、第二次改良標準化計画を経て、第三次改良標 準化計画では、改良型加圧水型軽水炉 (APWR) および改良 型沸騰水型軽水炉 (ABWR) が開発された。その後、次世代 軽水炉の開発を国のプロジェクトとして行ってきた。これ は電気出力 180 万 $\mathrm{kW}$ 級の軽水炉で Fig.4にあるように、 原子炉格納容器／原子炉建屋は航空機落下にも耐えられる 頑健性を備え、プラント寿命 80 年への対応を可能とする新 材料を採用し、ウラン燃料の長期燃焼を達成するなどの特 徵があり、次のような性能を目指している。

1) 優れた経済性:発電コストの低減（スケールメリット（大 電気出力)、高い稼働率 (目標 $97 \%$ )、燃料の長期燃焼 と燃焼効率向上、建設期間短縮と工程遵守（現行最新プ ラントの約 50 ケ月から 30 か月に削減)、プラント標準 化（建設地点の地震条件に依存しない設計、国際的な安 全規制や企画等に対応)。

2) 世界最高水準の安全性:安全性とセキュリティの強化 (原 子炉冷却のための放熱先を多様化 (大気と海水)）、パッ シブ系とアクティブ系の最適組合せによる世界最高水準 の安全性・経済性の同時実現、航空機落下にも耐えられ る原子炉格納容器／原子炉建屋、規制要求を超えるよう な事故を考慮した設備の設置、実績ある現行最新プラン トの安全設備を改良発展、耐震安全性の強化（大規模地 震に対する安全性)。

3) 人と環境にやさしいプラント:メンテナンス性の向上 (現 行最新プラントに比ベメンテナンス物量を大幅低減、最 新 IT 技術の活用によりメンテナンスを合理化)、環境へ の負荷低減（使用済燃料を $30 \%$ 以上低減、放射性廃棄 物を大幅低減、新材料により大型機器を長寿命化)。

次世代軽水炉の経済性は大電気出力によるスケールメ リットを狙ったものである。地域、電力会社によっては導 入のメリットがあるが、中・小型炉の方が適している場合 もある。 


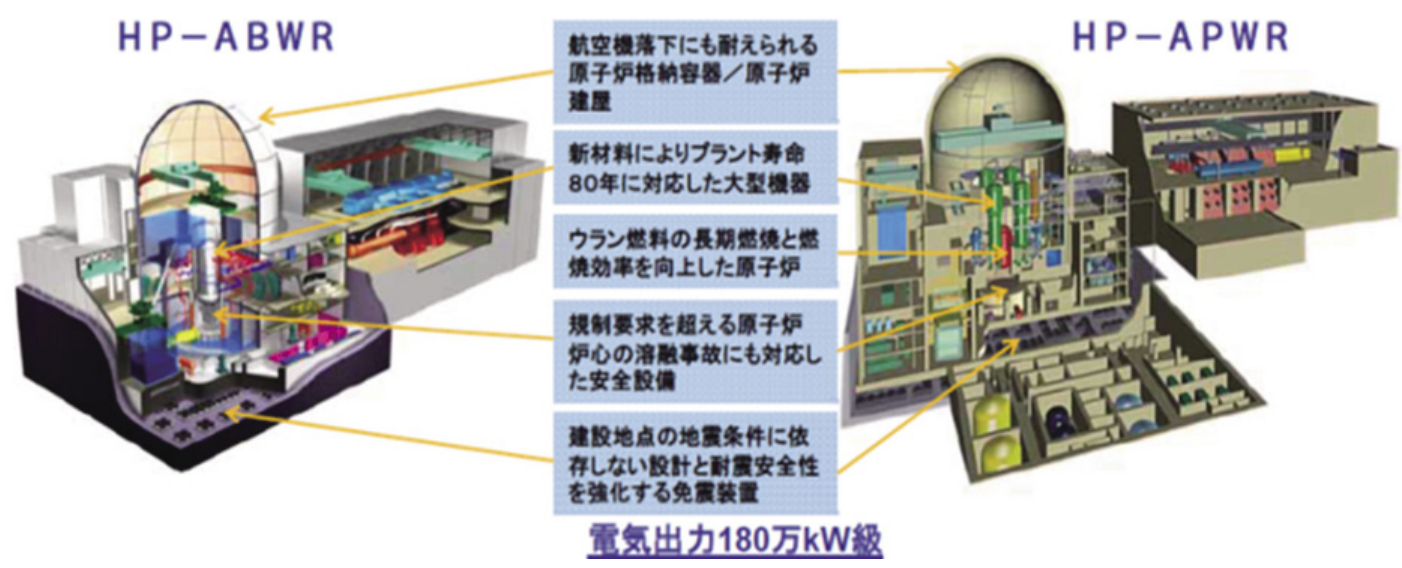

Fig.4 Future generation $\mathrm{LWR}^{1)}$

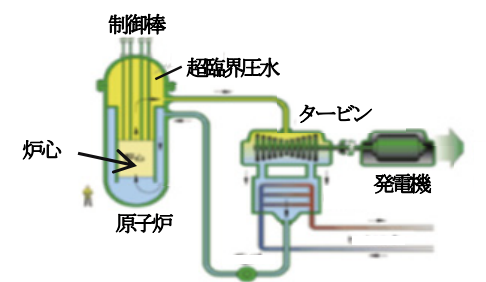

超臨界圧水冷却炉 - 超臨界水(220気压、 $374^{\circ} \mathrm{C}$ 以上) を た装霬のコンバクト化と梠勃革向上

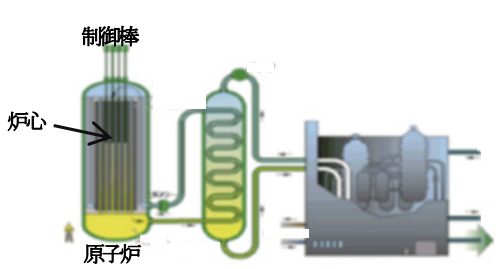

超高温ガス炉 ・高温ガス $\left(950^{\circ} \mathrm{C} \sim\right)$ の産莱利用

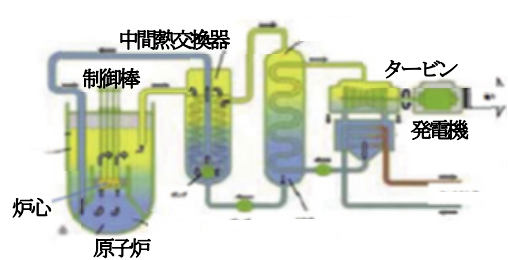

ナトリウム冷却高速炉

“技術的に最も成繁。革新技術の迸入 による安全·経济性等の向上

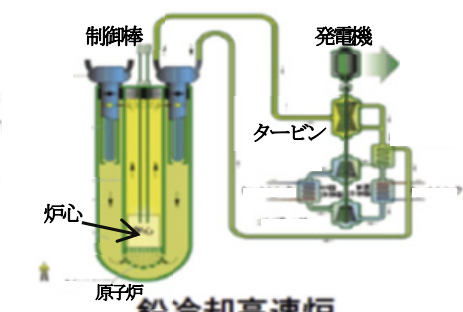

鉛冷却高速炉 " 化学的に二活性な+トリウムの代わりに 鉛を操用

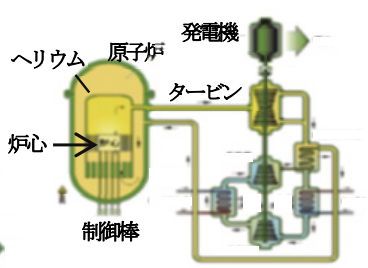

ガス冷却高速炉 ・化学的に活性なナ怰ムの代わりに ヘリウムガスを採用

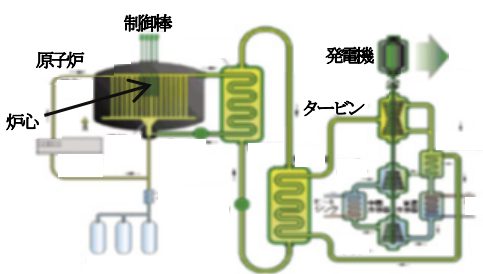

溶融塩炉

・トリウム媒料(液体妶料)を使用

Fig.5 Nuclear power systems selected in GIF $^{1)}$

\section{4. 第 4 世代原子力国際フォーラム (GIF) と INPRO ${ }^{1,2)}$}

GIF は国際協力による第 4 世代炉の開発であり、持続可 能性、経済性、安全性、信頼性（敷地外緊急時退避不要等）、 および核拡散抵抗性／核物質防護等の特徴を有するシステ ムとして第 4 世代炉の開発を進めることを目的としている。 持続可能性には、使用済核燃料に含まれるプルトニウムを 除いた超ウラン元素であるマイナーアクチニド (Am, Cm, $\mathrm{Np}$ など）の燃焼、核分裂による崩壊速度が非常に遅く半減 期すらも20万年を超えるような長寿命核分裂生成物の蓄 積防止などによる放射性廃棄物最小化、マイナーアクチニ ド燃焼によるウラン資源有効利用が含まれており、2030 年 頃の実用化を目指すとしている。現在のメンバーは、アル
ゼンチン、ブラジル、カナダ、フランス、日本、韓国、南 アフリカ、英国、米国、スイス、ユーラトム、中国、ロシ アである。このフォーラムでは、ナトリウム冷却高速炉、 ガス冷却高速炉、超高温ガス炉、超臨界圧水冷却炉、鉛冷 却高速炉、溶融塩炉の 6 つを候補概念としている (Fig.5)。 Table 1 にこれら 6 つの概念の概要を示す。特に、ナトリ ウム冷却高速炉は各国の協力により安全設計基準の国際化 を含め、実用化に向けた様々な取り組みが進展している。

GIFに近い国際協力プロジェクトとして、2001年に IAEAのプロジェクトとして設立された革新的原子炉 及び燃料サイクルに関する国際プロジェクト (INPRO: International Project on Innovative Nuclear Reactors and Fuel Cycles) がある。INPROの目的は、原子力エネルギーが持 
Table 1 Generation IV nuclear power systems considered in $\mathrm{GIF}^{2)}$

\begin{tabular}{|c|c|c|c|c|c|}
\hline システム & $\begin{array}{c}\text { 中性子 } \\
\text { スベクトル }\end{array}$ & 冷却材 & $\begin{array}{c}\text { 出口温度 } \\
\left({ }^{\circ} \mathrm{C}\right)\end{array}$ & 燓料サイクル & $\begin{array}{l}\text { 出力 } \\
\text { (MWe) }\end{array}$ \\
\hline $\begin{array}{c}\text { 超高温ガス冷却 } \\
\text { 妒(VHTR) }\end{array}$ & 珡中性子 & ヘリウム & $900-1000$ & オープン & $250-300$ \\
\hline $\begin{array}{c}\text { ナトリウム冷却 } \\
\text { 高速炉 } \\
\text { (SFR) }\end{array}$ & 高速中性子 & ナトリウム & $500-550$ & クロースト & $50-1500$ \\
\hline $\begin{array}{l}\text { 超壏界圧水椧 } \\
\text { 却炉(SCWR) }\end{array}$ & $\begin{array}{l}\text { 染中性子I } \\
\text { 高速中性子 }\end{array}$ & 水 & $510-625$ & $\begin{array}{l}\text { オーブンI } \\
\text { クロースト }\end{array}$ & $300-1500$ \\
\hline $\begin{array}{c}\text { ガス椧却高速炉 } \\
\text { (GFR) }\end{array}$ & 高速中性子 & ヘリウム & 850 & クローズド & 1200 \\
\hline $\begin{array}{c}\text { 鉛冷却高速炉 } \\
\text { (LFR) }\end{array}$ & 高速中性子 & 鉛 & $480-570$ & クロースト & $20-1200$ \\
\hline $\begin{array}{c}\text { 溶融塩炉 } \\
\text { (MSR) }\end{array}$ & $\begin{array}{c}\text { 慗中性子। } \\
\text { 高速中性子 }\end{array}$ & フッ化物塩 & $700-800$ & クローズド & 1000 \\
\hline
\end{tabular}

続可能性をもって 21 世紀のエネルギー需要に応えられるよ うにすることを支援する、および、技術保有国と利用国双 方の参加により、要求される革新的な原子炉及び燃料サイ クルを検討することである。加盟国は 38 ケ国と 1 機関（欧 州委員会 (EC : the European Commission)）である。INPRO は各国の長期のエネルギー戦略構築と INPRO 評価手法を 用いた原子力システムの評価、グローバルエネルギーシナ リオ、原子力技術の技術的・制度的検討、政策と対話といっ た活動を実施している。GIF との類似点は、共に次世代原 子力システムの研究開発に関する多国間協力枠組みであ り、将来的なエネルギー需要拡大に対応できる原子力シス テムの開発を進めるための情報交換を進めることにある。 一方、相違点は、GIF は原子力技術保有国のみで技術的テー マに関する協力が中心であるが、INPRO は将来のユーザ国 も含み、次世代原子力システム導入に向けた政策立案・イ ンフラ整備等、制度面に関する協力を主に実施しているこ とである。GIF, INPRO それぞれの特徴と目的を理解し、連 携して次世代原子力システムの研究開発を進めて行く必要 がある。

\section{5. 中小型炉、小型モジュール炉 (SMR: Small Module Reactor) $)^{1)}$}

上述の次世代軽水炉開発は大出力の炉を目指している が、地域によっては百万 $\mathrm{kW}$ ないし 50 万 $\mathrm{kW}$ 以下の電気出 力の中 · 小型炉が適している場合がある。離島や人口が少 ない地域など、送電網の発達していない場所においては、 原子炉を小型化・モジュール化することは魅力的であり、 軽水炉、高速炉、高温ガス炉、溶融塩炉について、米国、 フランス、ロシア、中国、韓国、日本などで研究開発が行 われている。とりわけ、燃料交換なしに 30 年間以上稼働 することが可能な小型炉・長寿命炉が注目されている。こ れらは実用化に近いものもあれば基礎的な概念検討レベル のものもある。PWR 型、BWR 型の中 · 小型炉については、 これまでの開発の経験が活かせるため、具体的な提案や検 討が多い。

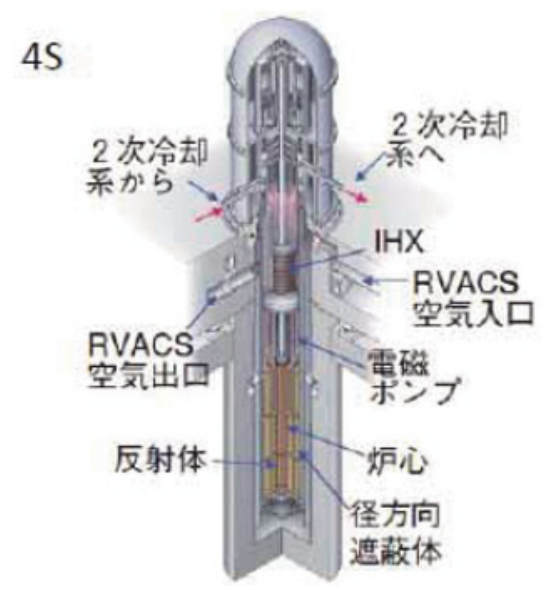

Fig.6 Small modular type fast reactor $4 S^{1)}$

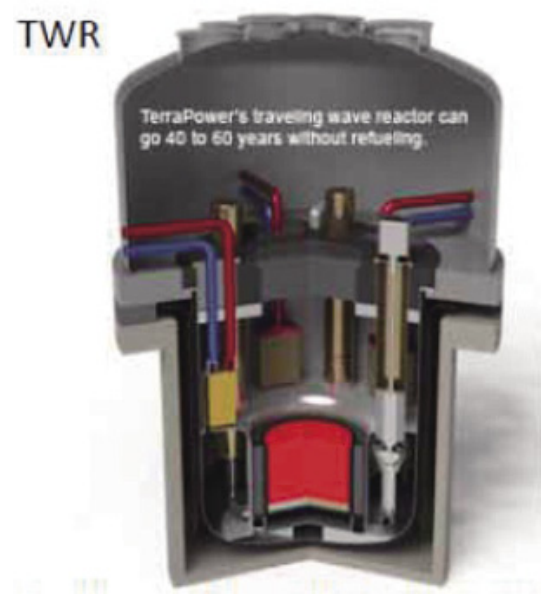

Fig.7 Traveling wave reactor (TWR) ${ }^{1)}$

Fig.6 は、東芝が開発した燃料交換不要な小型高速炉 4S (Super-Safe, Small and Simple) である。小型の原子炉が中性 子を漏らしやすい性質を利用し、中性子を反射する性質を もつ反射体を、燃料の燃焼させたい部分に移動させて部分 的に燃焼させるという、金属燃料を反射体で制御する方式 で、電気出力 1 万 $\mathrm{kW} 、 30$ 年間の炉心寿命を保持できる。 送電インフラのない地域等での電力供給、熱供給、海水淡 水化等、地域共生型の原子力多目的利用に貢献可能と考え られている。この炉は、現在米国でライセンス申請を計画 中である。

Fig.7 は、基礎的概念検討レベルにある進行波炉 (TWR: The Traveling Wave Reactor) である。ひとたび濃縮された燃 料を用いて燃焼進行が開始されれば、濃縮核燃料物質の追 加を必要とせずに、濃縮核燃料が燃焼したあとに残るウラ ン 235 の含有率が低い劣化ウランが存在する限り、発電が 継続するというものである。炉の燃焼制御方法、および大 


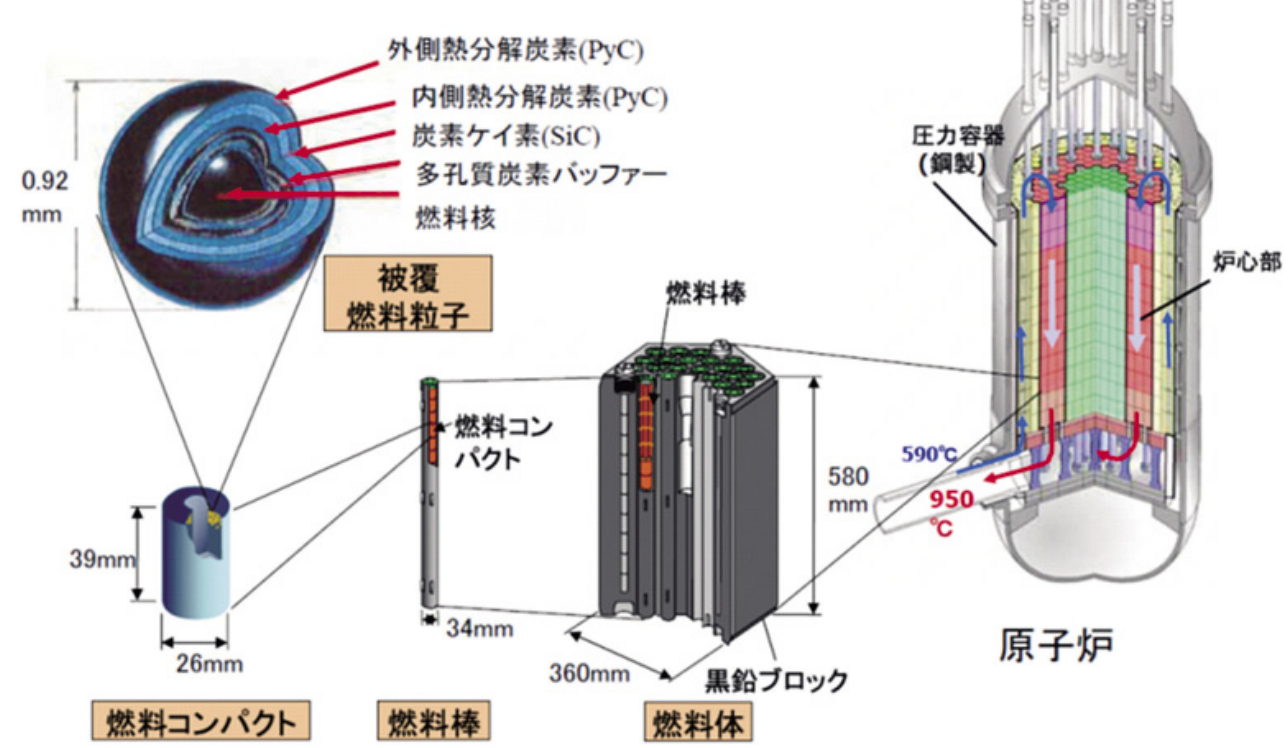

Fig.8 Fuel and reactor concept of high-temperature gas-cooled reactor ${ }^{3)}$

量の燃料を保有する点についての安全確保、長寿命炉心に 対応する材料が今後の課題である。

\section{6. 高温ガス炉 ${ }^{3)}$ 4)}

高温ガス炉は Fig.8のような被覆粒子燃料を用い、減速 材に黒鉛、冷却材にヘリウムを使用する原子炉で、冷却材 の出口温度は $800-950{ }^{\circ} \mathrm{C}$ 程度の高温になる。将来の原子炉 の一つとして注目されている。この高温ガス炉は次のよう な特徵を持っている。

1) 水素製造などへの核熱の利用可能性

冷却材出口温度が高いため、ガスタービンを介して発電 する場合には発電効率が $45-50 \%$ まで達する。また、高 い冷却材温度を活用して、熱源としての利用が注目されて いる。代表的なものは、高温ガス炉を熱源とする大規模水 素製造である。この他、製鉄、石炭ガス化、石油精製など も考えられる。

2) 高い固有安全性

燃料粒子の被覆セラミックスは耐熱性が高く、1600 ${ }^{\circ} \mathrm{C}$ 以 上の高温になっても健全性が保たれる。また、自然放熱に よる崩壊熱除去のみにより被覆材の過度の温度上昇を防ぐ ことができる。さらに減速材の黒鉛は熱容量が大きいため、 異常時および事故時の炉の温度上昇速度が緩慢であり、そ の間に冷却対策を実施しやすいこと。炉は大きな負の反応 度温度係数をもつことや、冷却材のへリウムが化学的に不 活性であることも特筆すべき点である。

3) 小型モジュール炉への適性

出力 10-30万 $\mathrm{kW}$ クラスの小型モジュール炉では、固有 安全性がより発揮される。すなわち、人的操作なく自然に
「止まり」、「冷えて」、放射性物質を燃料内に「閉じ込める」 という安全性を実現できる。また、小型炉では、ガスター ビンによる高発電効率による経済性向上も期待できる。

4) 核不拡散性向上、放射性廃棄物低減

高温ガス炬の被覆粒子燃料は長期間燃焼に対して安定で あるため、燃焼度を軽水炉燃料に比べて数倍程度高めるこ とができる。そのため、燃料中に生成されたプルトニウム を更に燃焼することができる。その後の使用済燃料は、再 処理することなく、深地層にそのまま処分しても長期健全 性が保たれることが期待される。まだ概念検討段階ではあ るが、将来のプルトニウム処理、廃棄物処理方法としても 注目される。

高温ガス炉の試験研究炉は、現在、日本、中国にある。 また、米国、ロシア、中国、カザフスタン等でも、実用炉 に向けたプラント実証プログラムが進んでいる。

南アフリカでは商用高温ガス炉発電プラント PBMR（ペ ブルベッドモジュラー炉) の建設計画が 1990 年代初めから 進められた。しかし、その後 2009 年の世界金融危機等の影 響等により計画は大幅縮小された。

\section{7. 発電用原子炉開発の重要性}

原子力発電の特徵は、ウラン資源が石油のように中近東 に偏在するのではなくオーストラルア、カナダ、カザフス タンなど政治的に安定なところにあること、資源備蓄効果 が大きいこと、発電コストが石炭火力並みと低いこと、運 転に伴って地球温暖化ガスを発生しないこと、高速増殖炉 システムが導入されれば資源利用期間は 1000 年以上になる ということなどである。安全確保は大前提であることはい 


$$
\text { スマートプロセス学会誌 第 } 3 \text { 巻 第 } 2 \text { 号 (2014 年 } 3 \text { 月) }
$$

うまでもない。安全神話に陥ることなく、深層防護の考え かたを具体的に適用しつつ、事業者等関倸組織が自らの責 務として継続的に安全向上に努めることにより、人と環境 を放射線の有害な影響から防護するという原子力安全の目 的を確実に達成する必要がある。このように原子力の潜在 的なリスクを顕在化させないようにしつつ、原子力の持つ 多くの特色を発揮させることが重要である。資源のそしい 我が国では原子力は将来も重要なエネルギー源であり、エ ネルギーセキュリティー確保に貢献することができる。

\section{8. まとめ}

今後の原子力発電について概説した。より安全性を高め た第 $3+$ 世代炉、第 4 世代炉の開発が行われている。GIF や INPRO という国際協力も有効に活用しながら進めて行く ことが重要である。また、大型の軽水炉だけでなく、中型炉、
小型炉の開発も重要である。その中で高温ガス炉は多くの 長所があり注目される。

\section{引用文献}

1）総合エネルギー調査会基本政策分科会第 8 回会合資料 (2013.10)

2) 佐賀山豊、日本原子力学会新型炉部会セッション資料 (2013.9.4)

3）岡本太志、大橋一孝：富士時報、83 (2010) 218-222.

4) エネルギー総合工学研究所、高温ガス炉プラント研究会資料 (2012)

\section{参考文献}

1)「原子カハンドブック」オーム社 (2007)

2)「原子力安全の基本的考え方についてー原子力安全の目的と基 本原則」日本原子力学会標準委員会技術レポート (2013) 